AUTHOR:

Miss Tanita Reddy ${ }^{1}$

Dr Yolandi Woest ${ }^{1}$

AFFILIATION:

${ }^{1}$ University of Pretoria, Pretoria, South Africa

DOI: http://dx.doi. org/10.18820/2519593X/pie. v39.i4.8

e-ISSN 2519-593X

Perspectives in Education

2021 39(4): 104-117

PUBLISHED:

6 December 2021

RECEIVED:

17 May 2021

ACCEPTED:

19 July 2021

\section{THE INFLUENCE OF LEARNER BEHAVIOUR ON BEGINNER TEACHERS' PERCEPTIONS OF THEIR OWN CREDIBILITY}

\begin{abstract}
Traditionally, teacher credibility has been influenced by how others perceive them. However, exploring teachers' own perceptions of their credibility through the observation of learner behaviour may prove to be meaningful to teacher credibility. The aim of this study was to explore Intermediate Phase beginner teachers' perceptions of their own credibility based on displayed learner behaviour in their classrooms. This qualitative study was presented through a case study research design. Eight Intermediate Phase beginner teachers were purposively selected. The data collection techniques used were interviews and observations. Semi-structured interviews and a researcher journal were used as data collection instruments. The data were analysed using inductive thematic data analysis. The conceptual framing of this study was underpinned by a modified theoretical model developed by McCroskey, Valencic and Richmond (2004). The findings showed that teachers' perceptions of their own credibility were fluid as they engaged with various learners' behaviour, which was used as a form of feedback during lessons and this feedback impacted teachers' reactions and decisions to classroom situations. Ultimately, teachers' perceptions of their own credibility focused on their immediacy, trustworthiness, competence and dynamism displayed in their practices.
\end{abstract}

Keywords: Beginner teachers; Intermediate Phase; learner behaviour; perceptions; South Africa; teacher credibility.

\section{INTRODUCTION}

As content conveyors, knowledge constructors and learning facilitators, teachers are in constant communication in the classroom. Under such intense surveillance (Page, 2017), it is important for teachers to consider their credibility as an influence on their practice. In its broadest sense, credibility is conceptualised as the degree of believability (Page \& Duffy, 2018). Hence, in the classroom context, teachers are placed in the position of enticing learners to believe in their communication of subject-related content. Teachers' credibility, which ultimately influences the overall quality of education (Cubukcu, 2013) and affects teachers' wellbeing (Shapiro, 2010), is foregrounded in daily classroom situations. 
Credibility is bound by time and context (Freeman, 2011). Thus, credibility is highly influenced by others' perceptions and may be likened to being under constant construction, deconstruction and reconstruction (Van Lankveld et al., 2017). Considering the highly influential nature of credibility, it is important to acknowledge teachers' perceptions of their own credibility (Freeman, 2011). As suggested by Freeman (2011), exploring teachers' views of their own practices provides a more valuable depiction of the classroom situation in terms of teachers' credibility through reflection. This study aimed to explore beginner teachers' perceptions of their own credibility based on the behaviour displayed by learners in Intermediate Phase (IP) classrooms.

IP beginner teachers within the South African schooling system are the focus population of this study. Winters and Cowen (2013) suggested that there is considerable growth in teacher quality within the initial five-year period in the profession. Therefore, the term "beginner teachers" refers to teachers in practice for up to five years. The General Education and Training band (GET) is the main category of compulsory schooling, which is further subdivided into phases called the Foundation Phase (Grades 0 to 3), the Intermediate Phase (Grades 4 to 6), and the Senior Phase (Grades 7 to 9).

\section{OVERVIEW OF LITERATURE}

The literature review is divided into two main sections, namely teachers and learners.

\subsection{Teachers}

\subsubsection{Teacher credibility}

Several studies over the years conceptualised credibility by making reference to various dimensions including: authoritativeness, goodwill and trustworthiness (Cooper, 1935); authoritativeness and character (McCroskey, 1966); immediacy (Mehrabian, 1967, 1969); competence, dynamism, objectivity and trustworthiness (Whitehead, 1968); and caring, character, competence and goodwill (McCroskey \& Teven, 1999). McGlone and Anderson (1973) directed their focus on teacher credibility in which the abovementioned credibility dimensions were compared and grouped to be used as umbrella terms when conceptualising teacher credibility in this study. Thus, the following teacher credibility dimensions were used: immediacy, trustworthiness, competence and dynamism (Berlo, Lemert \& Mertz, 1961; McCroskey, 1966; Mehrabian, 1967; Whitehead, 1968; McCroskey \& Young, 1981).

\subsubsection{Beginner teacher immediacy}

Conceptualised and established by Mehrabian, immediacy directs attention to the degree of physical and psychological closeness communicated between individuals (Mehrabian, 1969). Teacher immediacy was described by LeFebvre and Allen (2014) as the closeness shared between teachers and learners which influences verbal and nonverbal perceptions held by learners about their teachers. Learners rely heavily on teachers' verbal and nonverbal behaviours as communicative structures. These behaviours, in turn, affect how learners respond to various classroom situations (Claessens et al., 2017). Positive verbal communicative behaviours include words of affirmation, whilst negative verbal communicative behaviours include swearing, name calling and demotivating language, to name a few (LeFebvre \& Allen, 2014). Moreover, positive nonverbal communicative behaviours include regular eye contact, moving around the classroom, use of hand gestures and facial expressions, whilst negative 
nonverbal communicative behaviours include regular frowning, folded arms, standing behind an object, limited eye contact and inappropriate attire (LeFebvre \& Allen, 2014).

\subsubsection{Beginner teacher trustworthiness}

Within a communicative situation, trustworthiness refers to the extent to which the receiver is able to believe that what the source is saying is indeed true (Hovland, Janis \& Kelley, 1953). Trustworthiness is fundamentally linked to integrity and, in many cases, directed by one's already existing moral compass (Simons, 2002). Teven and Hanson (2004), for example, highlight the connection between immediacy and trustworthiness by stating that teachers who refrain from embarrassing and belittling their learners strengthen trustworthy relationships. In the classroom context, trust acts as the catalyst for an effective learning and teaching environment. Thus, learners confiding in their teachers, teachers providing guidance and support to their learners and teachers playing a role in their learners' holistic development all form elements of trustworthiness (Haskins, 2000).

In establishing trustworthiness in teacher-learner communication, Haskins (2000) foregrounded sincerity, honesty and believability as important communicative elements. The "openness" shared by beginner teachers in the classroom may allow learners to feel comfortable enough to engage in sincere discussions. Hence, when learners perceive their teachers to be honest, credibility is increased (Teven \& Hanson, 2004).

\subsubsection{Beginner teacher competence}

Competence, as described by Haskins (2000: 3), is "a perception that others have of people concerning their degree of knowledge on topics, abilities to command such knowledge, and abilities to communicate this knowledge clearly". Teachers are continuously being watched (Page, 2017) and tested on their knowledge of curriculum content. To be competent means to be prepared enough to control a lesson and actively facilitate intended learning (Teven \& Hanson, 2004). Haskins (2000) therefore emphasised the importance of relatability. Teachers need to continuously connect learners' prior knowledge to relevant contextual and cultural settings and experiences. This element enhances the competence of teachers and, overall, their credibility. Moss, Brookhart and Long (2011: 66) summed up competence by suggesting that teachers are able to "convey to students the destination for the lesson - what to learn, how deeply to learn it, and exactly how to demonstrate their new learning".

\subsubsection{Beginner teacher dynamism}

Dynamism is the extent to which learners admire and identify with their teachers in relation to the teachers' displayed charisma and energy (Haskins, 2000). Haskins (2000) stressed the importance of voice variation, body movement, and the use of visual stimuli to capture the learners' interest. Body language, facial expressions and eye contact are powerful tools that can be used to increase dynamism (Haskins, 2000), which is closely related to immediacy. Part of teacher credibility relates to developing a powerful style of speaking. Similar to competence, teachers need to learn the art of talking with limited vocal hesitation. To reinforce credibility, dynamic teachers string together aspects found in immediacy and competence. Reference is made not only to how intense and involved a teacher is in terms of dynamism but also to the vigour and panache added to a lesson, which strengthens the presence of dynamism (Haskins, 2000). 


\subsubsection{Intermediate Phase beginner teachers establishing their identities}

According to Ticknor (2014:290), identities are "plural, temporary, slippery, messy, contradictory, and full of tension with personal identities" and due to the notion that identities are time dependent, they tend to change based on situational and circumstantial factors that best suit the social settings. Thus, identities are also argued to be contextually dependent (Francis \& le Roux, 2011). Beginner teachers' identities are constructed using an array of elements including personal, professional, and social identity, which may be influenced by contextual variances (Freeman, 2011; Flores \& Day, 2006).

\subsubsection{Beginner teachers' perceptions}

Perception can be described as the judging of a situation or person within a specific context and based on preconceived notions (Shapiro, 2010). Perceptions are views that people use as a baseline to make sense of situations or people based on individual realities and world views (Sefotho, 2015). Hence, perceptions are a combination of belief systems based on subjective realities.

In this study, beginner teachers' perceptions were intertwined with teachers' establishment of their own identities. Freeman (2011) stressed the need to foreground both teachers and learners' perceptions for a more holistic and transparent overview of the educational needs in the classroom context. Once teachers have an overall understanding of their classroom and learners, relevant content can be relayed by observing displayed behaviours underpinned by verbal and nonverbal immediacy factors (Frymier \& Shulman, 1995).

\subsection{Learners}

\subsubsection{Intermediate Phase learners' behaviours}

According to Hudson (2012), the greatest challenge faced by beginner teachers is classroom and behaviour management. Stansbury and Zimmerman (2000) highlighted that beginner teachers in China, New Zealand and Switzerland perceived their greatest challenges to be classroom management, motivation of learners and the accommodation of individual differences amongst learners. In this study, learner behaviour was conceptualised using three components, namely learner discipline, learner interest and learner motivation.

\subsubsection{Learner discipline}

Learner discipline is described as the external management of learner behaviour within the classroom context (Kapueja, 2014). It thus becomes the teachers' responsibility to engage in understanding each learner in order to manage learner discipline. Discipline is the root of learning in which orderliness, structure and expectations are clearly outlined and strictly adhered to. Kapueja (2014) described learner discipline as a process of fostering and promoting acceptable behaviour such as listening while the teacher is teaching, raising of hands when asking questions and respecting peers. Conversely, unacceptable behaviours highlight actions of disobedience aimed at the teacher, displays of rude language in the classroom and incomplete homework.

Reyneke (2013) provided evidence that learner discipline is a common issue that South African teachers face in the classroom. Such disciplinary issues include "disruptive behaviour, rudeness, dishonesty, obscene language, cheekiness, untidy/incorrect clothing, neglect of duty, telling lies, and absenteeism on a daily, weekly or monthly basis" (Reyneke, 2013: 68). 
Moreover, according to Wolhuter, Oosthuizen and Van Staden (2010), factors of dishonesty, rebelliousness, cheekiness, disinterest, violence, vandalism, theft and bullying resulted in the highest occurrences in the Intermediate Phase. Hence, beginner teachers perceive their credibility in relation to displayed learner behaviour within the classroom by observing and monitoring learners' behaviours throughout their lessons.

\subsubsection{Learner interest and motivation}

Learner interest is closely coupled with learner motivation so productive learning occurs when the learners' full attention is engaged throughout a lesson. According to Renninger and Hidi (2019: 265), "[t]he components of interest include knowledge and value, which are usually accompanied by positive feelings". Learners exhibit interest in activities that they feel competent engaging in and completing. Learner interest is thus, to a large extent, based on learners' willingness to engage with the learning-specific subject areas where they feel the most knowledgeable. Such competencies are drawn from prior experiences such as doing well in assessments, being able to relate to discussed content and enjoying the content of the lesson.

Williams and Williams (2011) maintained that motivation is the key ingredient to quality education in enhancing and sustaining effective learning within the classroom. Motivation revolves around the concept of learner interest in which the learners display curiosity and awareness to content matter that is being taught (Williams \& Williams, 2011). Liu, Wang and Ryan (2016: 1) conceptualised motivation as "a force that activates, directs, and sustains goal-directed behaviour". More specifically, when learners feel a sense of involvement, they are more likely to be stimulated to answer questions and listen more intently, which will "drive and energize behaviour" (Liu et al., 2016: 1).

\subsubsection{Learner behaviour as a form of feedback}

Ünver (2014) highlighted the imperativeness of feedback in the classroom. This feedback from learners' use of language, paralinguistic cues or nonverbal behaviours supplies immediate responses to teachers based on content taught during lessons. Attentively monitoring learners' behaviour may allow teachers to take a closer look into the background of each learner. Using learner behaviour as a form of "immediate" feedback is closely linked to that of knowing one's learners well enough to detect sudden or out-of-character behavioural changes (McArthur \& Bostedo-Conway, 2012) and to then act on these behavioural changes accordingly.

Molloy and Boud (2013) suggested that feedback requires mutual communicative channels between teachers and learners. Therefore, both teachers and learners play crucial roles in establishing open and clear communication in the classroom. In terms of teachers using learners' behaviour as a means of feedback, it is important to remember that behaviour, much like identities, is inconsistent, time-bound and contextually dependent (Ticknor, 2014). However, using learner behaviour as a means of making short-term decisions, such as differentiating lessons, monitoring and managing learners' behaviour, and evaluating teachers' own emotional responses, should be considered and are highlighted in this study.

\section{CONCEPTUAL FRAMING}

A modified theoretical framework underpins this study that is used to develop the conceptual framing. The McCroskey et al. (2004) model for instructional communication entails the mutual exchange of information between teachers and learners with the intent of developing a 
constructive and progressive learning relationship (McCroskey et al., 2014). Learning, referring to this model, accommodates for inferences and synthesis of information to occur between learners and teachers (McCroskey et al., 2004). This model for instructional communication includes six interrelated components: the instructional environment, learners, teachers, teachers' verbal and nonverbal behaviours, instructional outcomes and learners' perceptions of the teachers (McCroskey et al., 2004).

Considering that much research focuses on learners' perceptions (McArthur \& BostedoConway, 2012) and this study focuses on IP beginner teachers' perceptions, it is important to propose the additional component of teachers' perceptions to the model. This addition to the model invites a more realistic outline of how IP beginner teachers' perceptions of their own credibility are influenced by learner behaviour displayed in a classroom context.

\section{RESEARCH METHODS AND DESIGN}

A case study design was employed to explore the participants' perceptions of displayed learner behaviour. The participants were private school, beginner teachers who taught in the Gauteng area in South Africa. As mentioned earlier, the beginner teachers had one to five years of teaching experience. The eight participants were representative of diverse races, which gave rise to a culturally diverse dataset. The participants were selected using the purposive sampling technique, specifically focusing on the availability and accessibility of the IP beginner teachers.

The data collection techniques used were interviews and observations, specifically semistructured interviews and written notes, whereby verbal and written data were collected. The first instrument used was semi-structured interviews with an average duration of one hour during which time 25 questions were asked, audio recorded, and thereafter transcribed. The second instrument included a researcher journal whereby additional observation notes were captured. Inductive thematic data analysis was used to analyse the data using colour coding and pattern finding (Nowell et al., 2017). Since qualitative studies are focused on exploring contextual aspects, interpreting phenomena and searching for meaning through inductive reasoning (Yilmaz, 2013), this allowed for subjectivity and interpretation in the decoding of data. The audio recordings of the interviews were listened to several times and compared to the transcripts for accuracy and validity purposes. The transcripts were then read through again and thereafter grouped according to themes, subthemes and categories.

The integrity of the study was maintained by ensuring trustworthiness and credibility. A researcher journal captured and guided the research process to ensure that the findings were transparent and reliable. Ethical clearance was obtained (HU 17/03/03) from the Ethics Committee at the University of Pretoria and all the participants were aware of the particulars of their consent, as stated in the consent form. The participants were aware that their participation was voluntary at all stages of the research process. Their privacy, confidentiality, and anonymity were protected using pseudonyms in place of real identities and schools' names. No harm to the participants resulted from this research.

\section{FINDINGS}

Data from this study showed that most of the participants reported using their learners' behaviour to adapt their teaching styles and methods. Thus, the learners' behaviour was used as a form of feedback that influenced their lessons. In the participants' observations 
of their classroom situations, it was also mentioned that dealing with and managing learner behaviour affected their lessons. The participants explained that using their schools' policies when dealing with the learners' behaviour played an important role in directing their reactions.

However, some beginner teachers reported that there were discrepancies between what was expected from teachers in response to learners' behaviour versus the reality of the classroom situations. Some teachers believed that their own behaviour in classroom situations, such as how they responded to the learners' behaviour, directly influenced that behaviour. The study's findings were grouped into three themes: beginner teachers' adaptation methods of lessons based on learner behaviour; dealing with learner behaviour in alignment with school policies and the influence of beginner teachers' emotional responses on learners' behaviour.

\subsection{Beginner teachers' adaptation methods of lessons based on learner behaviour}

Teachers' awareness of their own observations of learners' behaviour could encourage adaptation of lessons to relay content effectively. The data showed that some teachers were eager to modify their lessons to best suit their learners' needs based on their observations of the learners' behaviour. Some teachers mentioned that using practical content allowed for active engagement by learners. Through this method, teachers could immediately identify and distinguish between those learners who understood and those who did not.

The teachers below stressed the need to accommodate diverse learning needs and styles. These teachers highlighted the importance of knowing learners individually in order to create content that was relatable and inclusive:

...we either have a little shop and we're selling things, to introduce money, or we have clocks and we work with the clock with time, where I just explain, well, let them experience it a bit, and then we explain... (Participant 4, interview on 25 May 2017)

Another teacher associated her teaching with actively involving her learners in the lesson:

We will try to do the lesson also practically, by doing, I will get them involved by say for example I am teaching Afrikaans then we will get up in class and I will say, "Okay get, staan op jou stoel," [Okay, get up and stand on your chair] and then they will stand up and stand on their chairs. (Participant 7, interview on 07 June 2017)

Other teachers explained that their learners' behaviour provided feedback as to what had been taught. When learners did not understand the taught content, their levels of interest and motivation decreased and that was where teachers identified a change in learners' behaviour. At this point, differentiation of teaching methods began, based on the received behavioural feedback "...when learners are attentive and they are focused on their work and they listen" (Participant 1, interview on 18 May 2017).

Another teacher mentioned that the learners' behaviour confirmed the learners' interest and motivation:

You can also pick up the vibe in the class. When I would ask them a question and multiple hands come up and people will stand on the desk and then people are like, "Pick me! Pick me!" (Participant 6, interview on 06 June 2017). 
The responses of these beginner teachers revealed that their awareness of their perceptions of their learners' behaviour influenced their willingness to adapt their lessons to accommodate learners' needs.

\subsection{Dealing with learner behaviour in alignment with school policies}

This theme is associated with beginner teachers holistically developing their learners to become responsible citizens of the world. Operant conditioning was a behaviourist theory founded by B.F. Skinner, who justified a stimulus-response mechanism (Passer et al., 2009). Using positive and negative reinforcements were based on rewarding acceptable behaviours and ignoring unacceptable behaviours (Passer et al., 2009). Some teachers explained that the use of positive reinforcements was preferred and encouraged by their schools:

Well, I am, at our school we've got a positive behaviour approach, to discipline, where we only have five rules in the classroom, and we focus a lot on encouraging and praising positive behaviour, and less on the negative behaviour (Participant 4 , interview on 25 May 2017).

One teacher highlighted the importance of refraining from demotivating learners:

We have got a system at school where we rather award the children for good behaviour than demotivate the children by giving demerits so we rather use positive reinforcement (Participant 7, interview on 07 June 2017).

Another teacher reported that her school followed a system of "peace makers" and "peace breakers" that focused on learners' behaviours and choices. She further explained that she used a group behaviour approach where she highlighted the consequences and responsibilities of each learner:

If they get a minus one as a class - just because of one person - then the positive peer pressure comes in. They are able to adjust each other; adjust themselves - so they learn, "Okay, there is a consequence for everything that we do, and it also didn't just affect me but it can affect those around me" (Participant 5, interview on 05 June 2017).

One of the teachers viewed learner behaviour as a result of consistent structure and routine. She stressed the need for teachers to communicate classroom rules, roles and expectations to learners with the aim of setting boundaries and teaching learners about accountability:

Well from the first minute you have to have good discipline outside of the classroom before they come in, and they stand behind their chairs and would properly greet each other. Uhm they would know from day one as well what the rules in the classroom are and everybody will have to just sign that they agree with the class rules. We also have a discussion in the classroom, uhm and they can also give their ideas of the classroom rules (Participant 7, interview on 07 June 2017).

The above responses indicate that several beginner teachers in this study encountered challenges in dealing with learner discipline. They mostly agreed with following their schools' policies in managing learner behaviour. Many of the beginner teachers highlighted that positive reinforcement was more commonly used and preferred according to their schools' policies which influenced the methods used in their classrooms. 


\subsection{The influence of beginner teachers' emotional responses on learner behaviour}

As outlined by McCroskey et al. (2014), instructional communication is a culmination of various components that influence each other. Since the aim of this study was to understand IP beginner teachers' perceptions of their own credibility based on displayed learner behaviour within the IP classroom, it became increasingly important to consider the influence of teachers' emotional responses to learners' behaviour. The teachers confirmed that their behaviour affected the learners' behaviour:

So, I also think that it [learner behaviour] depends on the teacher as well, because if I am like in a bad mood and I am like very strict with them, then automatically that will also influence their behaviour (Participant 4, interview on 25 May 2017).

Another teacher supported this point:

Well, if, if I am feeling a little bit down the day and uhm, ja [yes] I am not in a good mood, the children definitely pick up on stuff like that, uhm they, they won't be as enthusiastic, uhm if I don't show a lot of energy, they tend to also not show a lot of energy (Participant 7, interview on 07 June 2017).

However, some teachers shared that they were under immense pressure and that managing the daily pressures of teaching influenced their emotional responses (Shapiro, 2010). Another beginner teacher emphasised that teachers were expected to segment their own emotions from their classroom personas:

I'd rather focus on the kids and their problems and everything than my own. It was kind of the case where I felt like breaking down but some of the kids were coming to me crying and I just had to breathe and just put them first and I carried on that way (Participant 2, interview on 22 May 2017).

The findings revealed that teachers were aware that they too were being observed by learners (Page, 2017) and that their emotions did indeed influence their learners' behaviour. Most of the participants declared that managing their own emotions was important but they believed that learners' needs and emotions should be dealt with first. The teachers explained that their personal feelings or moods should not affect their behaviour towards their learners, alluding to the need to separate their personal emotion from their practice.

\section{DISCUSSION OF FINDINGS}

This study foregrounded three important findings. These findings showed that the IP beginner teachers used their observations of learner behaviour to adapt their teaching methods and thus deal with and respond to learners' behaviour accordingly.

\subsection{Adaptation of teaching methods}

The first important finding relates to the beginner teachers adapting their teaching methods based on observed learner behaviour. According to the underpinning theoretical model (McCroskey et al., 2004), teachers and learners are the main elements within the classroom. The data from this study revealed the significance of observations and awareness of learners' behaviour from teachers within the instructional environment. Two out of the eight participants stressed the importance of making lessons practical and encouraging active participation from learners as a method of adapting lessons. Knowing the learners and their needs was 
emphasised by most of the participants in directing teachers to make informed decisions about how to adapt lessons effectively. In creating and sustaining comfortable learning environments, teachers highlighted the need to know their learners' strengths and weaknesses (Cubukcu, 2013).

\subsection{Dealing with learners' behaviour}

The second important finding of this study is how the beginner teachers deal with learners' behaviour in accordance with their school policies. This theme highlights the instructional environment component in the conceptual framing (McCroskey et al., 2004), foregrounding the proposed methods of dealing with learner behaviour using the schools' policies. The data from this study showed that most of the teachers used their school policies to shape and guide their methods of dealing with their learners' behaviour. Five out of the eight beginner teachers shared that they used operant conditioning techniques in their practices (Skinner, 1985) which was in alignment with their schools' policies. Several of the teachers refrained from using negative reinforcement, as this was not a method that was encouraged by their schools. A few of the teachers expressed the thought that relying solely on positive reinforcement posed challenging behavioural situations. This forced teachers to find methods better suited to dealing with learners' behaviour.

In response to dealing with persistent unwanted learner behaviour, some teachers felt that getting to know their learners enabled them to use their own strengths to manage the unwanted behaviour displayed by the learners and to follow a value-driven approach in stressing the development of moral accountability. Moreover, Rahimi and Karkami (2015)recognition/ reward, discussion, involvement, and aggression supported several of the teachers' claims related to establishing structure and routine within the classroom. The teachers explained that by making learners aware of their expectations, roles and responsibilities, a better sense of judgement and decision-making by the learners was observed.

\subsection{The influence of teachers' behaviour on learners' behaviour}

The third important finding is that the beginner teachers' emotional responses do indeed influence the learners' behaviour. According to the underpinning conceptual framing (McCroskey et al., 2004), this theme relates specifically to the influence of teachers' verbal and nonverbal behaviours. The findings of this study, as proposed by the adapted conceptual framing, suggest that as learners' behaviour influences teachers' perceptions of their own credibility, the teachers' behaviour influences learners' perceptions.

This theme foregrounds the complexity of the credibility construct and reiterates the plurality of perceptions (Sefotho, 2015). Some teachers admitted that their emotional reactions influenced their learners' behaviour (Bruney, 2012), whereas others explained the need to separate their emotions from their practice and to mask their emotions in order to deal with learners' emotional needs (Shapiro, 2010). Hence, in the construction, deconstruction and reconstruction of teachers' perceptions of their own credibility (Van Lankveld et al., 2017), the inevitable interjection of their own behaviour influencing the learners' behaviour has value and should be considered. The three themes outlined in this study relate to the four credibility dimensions of immediacy, trustworthiness, competence and dynamism. The beginner teachers referred to at least one of the four credibility dimensions in their responses. In Theme 1, the beginner teachers mentioned having to be flexible and willing to adapt their lessons when the behaviour displayed by the learners did not meet their expectations, such as learners 
becoming disruptive or disinterested. Also, the teachers explained that ensuring a safe and open atmosphere in allowing learners to feel included and teachers to know their learners enabled teachers to be better prepared in knowing how to adapt lessons (trustworthiness and competence). In Theme 2, some teachers expressed that knowing learners' strengths and weaknesses assisted in managing and dealing with learners' discipline more effectively by assigning learner responsibilities appropriately (immediacy and dynamism). In Theme 3 , some teachers were aware that their moods and emotional responses influenced their learners' behaviour, whilst others explained that they separated their personal and professional emotions (immediacy and dynamism).

\section{CONCLUSION}

Learner behaviour may be used as a form of feedback to beginner teachers in assisting with the adaptation of lessons to better suit learners' learning needs. It is important for teachers to become aware of the hidden messages behind their learners' behaviour and to redirect this feedback as a platform to implement differentiation in lessons. Learners' perceptions are a crucial segment in the effectiveness of the development and implementation of classroom rules. This study highlighted that beginner teachers relied on and were guided by their schools' policies when dealing with learners' behaviour. However, in some instances, the implementation of these policies needed to be modified in order to better manage learners' behaviour. These modifications in lessons and behaviour influenced beginner teachers' perceptions of their own credibility, which was conceptualised using four main dimensions: immediacy, trustworthiness, competence and dynamism.

\section{REFERENCES}

Berlo, D.K., Lemert, J.B. \& Mertz, R. 1961. A factor analytic study of the dimensions of source credibility. In Report of the Convention of the Speech Association of America, New York.

Bruney, G. 2012. The teacher-student relationship: The importance of developing trust and fostering emotional intelligence in the classroom. Research paper, University of Toronto.

Claessens, L.C.A., Van Tartwijk, J., Van der Want, A.C., Pennings, H.J M., Verloop, N., Den Brok, P.J. \& Wubbels, T. 2017. Positive teacher-student relationships go beyond the classroom, problematic ones stay inside. Journal of Educational Research, 110(5): 478-493. https://doi.org/10.1080/00220671.2015.1129595

Cooper, L. 1935. The Rhetoric of Aristotle. Quarterly Journal of Speech, 21(1): 10-19. https:// doi.org/10.1080/00335633509380070

Cubukcu, F. 2013. Student teachers' perceptions of teacher competence and their attributions for success and failure in learning. The Journal of International Social Research, 3(10): 213-217.

Flores, M. A. \& Day, C. 2006. Contexts which shape and reshape new teachers' identities: A multi-perspective study. Teaching and Teacher Education, 22(2): 219-232. https://doi. org/10.1016/j.tate.2005.09.002

Francis, D. \& le Roux, A. 2011. Teaching for social justice education: The intersection between identity, critical agency, and social justice education. South African Journal of Education, 31(3): 299-311. https://doi.org/10.15700/saje.v31n3a533 
Freeman, N.P.M. 2011. Credibility and the professor: The juxtaposition of student perceptions and instructor beliefs. Unpublished PhD dissertation. Missouri: University of Central Missouri.

Frymier, A.B. \& Shulman, G.M. 1995. 'What's in it for me?': Increasing content relevance to enhance students' motivation. Communication Education, 44(1): 40-50. https://doi. org/10.1080/03634529509378996

Haskins, W.A. 2000. Ethos and pedagogical communication: Suggestions for enhancing credibility in the classroom. Available at https://cie.asu.edu/ojs/index.php/cieatasu/article/ view/1616 [Accessed: 12 April 2021].

Hovland, C., Janis, I. \& Kelley, H. 1953. Schlüsselwerke der Medienwirkungsforschung. Schlüsselwerke Der Medienwirkungsforschung, Springer VS.

Hudson, P. 2012. How can schools support beginning teachers? A call for timely induction and mentoring for effective teaching. Australian Journal of Teacher Education, 37(7): 71-84. https://doi.org/10.14221/ajte.2012v37n7.1

Kapueja, I.S. 2014. Discipline in schooling: A study of rural secondary schools in KwazuluNatal. Unpublished PhD dissertation. Durban: University of Zululand.

LeFebvre, L. \& Allen, M. 2014. Teacher immediacy and student learning: An examination of lecture/laboratory and self-contained course sections. Journal of the Scholarship of Teaching and Learning, 14(2): 29-45. https://doi.org/10.14434/josotl.v14i2.4002

Liu W.C., Wang J.C.K., \& Ryan R.M. 2016. Understanding motivation in education: Theoretical and practical considerations. In W. Liu, J. Wang \& R. Ryan (Eds.). Building Autonomous Learners. Singapore: Springer. https://doi.org/10.1007/978-981-287-630-0_1

McArthur, J.A. \& Bostedo-Conway, K. 2012. Exploring the relationship between studentinstructor interaction on Twitter and student perceptions of teacher behaviors. International Journal of Teaching \& Learning in Higher Education, 24(3): 286-292.

McCroskey, J.C. 1966. Scales for the measurement of ethos. Speech Monographs, 33(1): 65-72. https://doi.org/10.1080/03637756609375482

McCroskey, J.C. \& Teven, J.J. 1999. Goodwill: A re-examination of the construct and its measurement. Communications Monographs, 66(1): 90-103. https://doi. org/10.1080/03637759909376464

McCroskey, J.C., Valencic, K.M. \& Richmond, V.P. 2004. Toward a general model of instructional communication. International Journal of Phytoremediation, 52(3): 197-210. https://doi.org/10.1080/01463370409370192

McCroskey, J.C. \& Young, T.J. 1981. Ethos and credibility: The construct and its measurement after three decades. Central States Speech Journal, 32(1): 24-34. https://doi. org/10.1080/10510978109368075

McCroskey, L.L., Teven, J.J., Minielli, M.C. \& Richmond McCroskey, V.P. 2014. James C. McCroskey's instructional communication legacy: Collaborations, mentorships, teachers, and students. Communication Education, 63(4): 283-307. https://doi.org/10.1080/03634523.201 4.911929

McGlone, E.L., \& Anderson, L.J. 1973. The dimensions of teacher credibility. The Speech Teacher, 22(3): 196-200. https://doi.org/10.1080/03634527309378015 
Mehrabian, A. 1967. Attitudes inferred from neutral verbal communications. Journal of Consulting Psychology, 31(4): 414-417. https://doi.org/10.1037/h0024834

Mehrabian, A. 1969. Some referents and measures of nonverbal behavior. Behavior Research Method and Instruction, 1(6): 203-207. https://doi.org/10.3758/BF03208096

Molloy, E. \& Boud, D. 2013. Chapter 2: Changing conceptions of feedback. In E. Molloy \& D. Boud (Eds.). Feedback in higher and professional education (pp. 11-33). London: Routledge.

Moss, C.M., Brookhart, S.M. \& Long, B.A. 2011. What is a shared learning target? Educational Leadership, 68(6): 66-69.

Nowell, L.S., Norris, J.M., White, D.E. \& Moules, N.J. 2017. Thematic analysis: Striving to meet the trustworthiness criteria. International Journal of Qualitative Methods, 16(1): 1-13. https://doi.org/10.1177/1609406917733847

Page, D. 2017. The surveillance of teachers and the simulation of teaching. Journal of Education Policy, 32(1): 1-13. https://doi.org/10.1080/02680939.2016.1209566

Page, J.T. \& Duffy, M.E. 2018. What does credibility look like? Tweets and walls in U.S. presidential candidates' visual storytelling. Journal of Political Marketing, 17(1): 3-31. https:// doi.org/10.1080/15377857.2016.1171819

Passer, M., Smith, R., Holt, N., Bremner, A., Sutherland, E. \& Vliek, M. 2009. Psychology: The science of mind and behaviour. Wales: McGraw-Hill.

Rahimi, M. \& Karkami, F.H. 2015. The role of teachers' classroom discipline in their teaching effectiveness and students' language learning motivation and achievement: A path method. Iranian Journal of Language Teaching Research, 3(1): 57-82.

Renninger, K.A. \& Hidi, S.E. 2019. Interest development and learning. In K.A. Renninger \& S.E. Hidi (Eds.). The Cambridge handbook of motivation and learning (pp. 265-290). Massachusetts: Cambridge University Press. https://doi.org/10.1017/9781316823279.013

Reyneke, J.M. 2013. The best interests of the child in school discipline in South Africa. Unpublished PhD dissertation. Netherlands: Tilburg University.

Sefotho, M.M. 2015. A researcher's dilemma: Philosophy in crafting dissertations and theses. Journal of Social Sciences, 42(1-2), 23-36. https://doi.org/10.1080/09718923.2015.11893390

Shapiro, S. 2010. Revisiting the teachers' lounge: Reflections on emotional experience and teacher identity. Teaching and Teacher Education, 26(3): 616-621. https://doi.org/10.1016/j. tate.2009.09.009

Simons, T. 2002. Behavioral integrity: The perceived alignment between managers' words and deeds as a research focus. Organization Science, 13(1): 18-35. https://doi.org/10.1287/ orsc.13.1.18.543

Skinner, B.F. 1985. Cognitive science and behaviourism. British Journal of Psychology, 76(3): 291-301. https://doi.org/10.1111/j.2044-8295.1985.tb01953.x

Stansbury, K. \& Zimmerman, J. 2000. Lifelines to the classroom: Designing support for beginning teachers. San Francisco: WestEd.

Teven, J.J. \& Hanson, T.L. 2004. The impact of teacher immediacy and perceived caring on teacher competence and trustworthiness. Communication Quarterly, 52(1): 39-53. https://doi. org/10.1080/01463370409370177 
Ticknor, A.S. 2014. Negotiating professional identities in teacher education: A closer look at the language of one preservice teacher. New Educator, 10(4): 289-305. https://doi.org/10.10 80/1547688X.2014.965094

Ünver, G. 2014. Connecting theory and practice in teacher education: A case study. Educational Sciences: Theory \& Practice, 14(4): 1402-1407. https://doi.org/10.12738/estp.2014.4.2161

Van Lankveld, T., Schoonenboom, J., Volman, M., Croiset, G. \& Beishuizen, J. 2017. Developing a teacher identity in the university context: A systematic review of the literature. Higher Education Research and Development, 36(2): 325-342. https://doi.org/10.1080/0729 4360.2016.1208154

Whitehead, J.L. 1968. Factors of source credibility. Quarterly Journal of Speech, 54(1): 59-63. https://doi.org/10.1080/00335636809382870

Williams, K.C., \& Williams, C.C. 2011. Five key ingredients for improving student motivation. Available at http://aabri.com/manuscripts/11834.pdf [Accessed: 14 April 2021].

Winters, M.A. \& Cowen, J.M. 2013. Would a value-added system of retention improve the distribution of teacher quality? A simulation of alternative policies. Journal of Policy Analysis and Management, 32(3): 634-654. https://doi.org/10.1002/pam.21705

Wolhuter, C.C., Oosthuizen, I. \& Van Staden, J. 2010. Skoolfase/leerderouderdom as faktor in leerderdissipline in Suid-Afrikaanse skole. Tydskrif Vir Christelike Wetenskap, 46(1): 169-186.

Yilmaz, K. 2013. Comparison of quantitative and qualitative research traditions: Epistemological, theoretical, and methodological differences. European Journal of Education, 48(2): 311-325. https://doi.org/10.1111/ejed.12014 